\title{
Are Self-Talk and Mental Toughness Level Prerequisites Besides the Kick Boxing Education Level in Athletes?
}

\author{
Yasemin YALÇIN $^{1}$ \& Fatma TURAN ${ }^{1}$ \\ ${ }^{1}$ Department of Physical Education and Sports, Faculty of Sports Sciences, Alanya Alaaddin Keykubat \\ University, Alanya, Turkey \\ Correspondence: Yasemin YALÇIN, Department of Physical Education and Sports, Faculty of Sports Sciences, \\ Alanya Alaaddin Keykubat University, Alanya, Turkey.
}

Received: June 2, 2021

doi:10.5539/ies.v14n10p105
Accepted: July 25, $2021 \quad$ Online Published: September 26, 2021

URL: https://doi.org/10.5539/ies.v14n10p105

\begin{abstract}
The aim of this study is to determine the relationship between self-talk and mental toughness levels of kickboxers and to compare the differences between the self-talk and mental toughness of the athletes according to the independent variables obtained from the personal information of the athletes participating in the research. The study group of the research consists of athletes who participated in kickboxing competitions in Turkey ( $\mathrm{n}=223$ ). $120(53.8 \%)$ of the athletes are women and $103(46.2 \%)$ are men. In the study, the "Self-Talk Questionnaire" adapted to the Turkish athlete population by Engür (2011) and the "Sport Mental Toughness Questionnaire" adapted to Turkish by Altıntaş and Bayar Koruç (2016) is used. It is decided whether the data met the prerequisites of the parametric tests by examining the Skewness and Kurtosis values (normal distribution of the data) and the Levene test (equality of variance) results. As a result, correlation analysis is used to determine the relationships between the variables, and t-test and ANOVA analyses are used to determine the differences. As a result of the research, it is determined that there is a positive and significant relationship between self-talk and mental toughness. Mental toughness is accepted as a term that trainers, managers and athletes attach importance to, and it is considered a prerequisite for sportive success. The fact that there is a positive and significant relationship between self-talk and mental toughness suggests that self-talk is also a predictor of performance. At the point of achieving success, the inner messages that the athlete will give themselves will increase their mental toughness and will be reflected in the sports environment, training or competition.
\end{abstract}

Keywords: self-talk, mental toughness, kick boxing education

\section{Introduction}

Sport is considered as a tool that helps people to develop in every way and provides the development of knowledge, skills and leadership abilities in individuals. At the same time, it helps individuals to eliminate the problems they will encounter and to discipline themselves (Açıkada \& Ergen, 1990). Human is the most important element of sports, a concept that has maintained its place in society for centuries and is increasing in importance every year (Engür, 2011). The concept of sport has survived from ancient times to the present day. It appears as a product of the struggle of people to protect themselves from wild animals and to find food, that is, to ensure their survival.

With the increase in the value given by the society to sports, the importance of high achievement has also increased. The physical work done by the athletes in displaying this success is not enough on its own. In addition to the technical, tactical, conditioning and toughness activities of the athlete, their psychological status has also been among the important factors. In general, when it is desired to achieve superior success in athletes, it is important to carry out psychological studies together with physical studies and to ensure continuity (Bingöl, 2020). Here, the value of the training given to the athletes through the coaches is understood better.

Sports psychology is a science that examines the behavior and thoughts of the athlete and tries to increase the performance of the athlete and the coach.

The main purpose of sports psychology is to find out how psychological elements affect the success of the athlete and to what extent they contribute to their psychological development (Aşcı \& Kirazc1, 2003).

It has been determined that researches on mental activities in the field of sports sciences have increased in recent 
years. It has been stated that these studies are carried out to observe the psychological movements of the athlete (Bingöl, 2020). Among the mental techniques commonly used in sports practices, self-talk is seen as the subject of the current research (Hardy, Oliver, \& Tod, 2009).

The individual frequently uses self-talk during the day. From the perspective of athletes and trainers, self-talk, in other words, internal monologue or covert speaking, is one of the important methods in improving sportive success (Shannon et al., 2012; Thelwell et al., 2008; Vargas et al., 2004).

If we define self-talk, it is a series of discourses that we carry out to ourselves at a time when we are thinking about any topic. Although self-talk is examined with different structures by many researchers, according to Weinberg and Gould (2014), it is seen that it is examined in 3 parts as positive self-talk, negative self-talk and instructional self-talk.

Self-talk increases the confidence of the athletes in order to reach their sportive goals in their psychological resilience and helps them on how to reach these goals (Engür, 2011). In addition to increasing concentration, self-talk has many potential uses, including getting rid of bad habits, increasing mental readiness, initiating behavior, maintaining effort, and acquiring skill (Weinberg \& Gould, 2014). Studies have shown that self-talk is associated with sportive success and determined that mental processes reveal physical performance.

It can be said that the athletes who are unique in sports competitions, who are not defeated, who result in superiority despite the adversities encountered, who succeed even when competing under all difficult conditions, reach a certain level of mental toughness (Mahoney, Ntoumanis, Mallett, \& Gucciardi, 2014). The term mental toughness in sports has been increasing its importance recently. It is accepted as a term that trainers, managers and athletes attach importance to, and it is considered a prerequisite for sportive success (Jones, Hanton, \& Connaughton, 2007).

Studies conducted in recent years have focused on the importance of psychological and mental toughness on the athletic success of athletes (Jones et al., 2007). Mental toughness can be explained with a number of psychological concepts used for high-level performance in the face of negative results (Clough, Earle, \& Sewell, 2002). Today, in addition to the physical competence of the athletes, it has been adopted that mental toughness and psychological competence are considered effective in order to achieve high success in competitions (Jackson, Thomas, Marsh, \& Smethurst, 2001).

Kickboxing is an individual combat sport. As in many branches, self-talk and mental toughness are very important in kickboxing. The athlete's directing themselves to positive conversations will provide positive feedback. Positive self-talk during or after the competition will help the athlete perform well and increase their mental stamina. A few of the issues addressed in studies conducted in this context are as follows: In the study conducted by Engür (2011), it is determined that motivational function and cognitive function, which are the sub-dimensions of self-talk, are related to sports experience. Fear of failure is found to be associated with some of the sub-dimensions of self-talk. In the study conducted by Bayköse (2014), it is not found that there is a statistical difference between the levels of self-talk in terms of sports experience of amateur and professional athletes.

The aim of this research is to determine the relationship between self-talk and mental toughness levels of kickboxers and to compare the differences between the self-talk and mental toughness of the athletes according to the independent variables obtained from the personal information of the athletes participating in the research.

Today, one of the basic requirements for athletes to exhibit a desired performance is to have the necessary psychological competencies. Scientists who examine the basic requirements for the success of athletes all over the world have done more studies on the importance of physical characteristics, and they have paid less attention to studies on psychological characteristics. Therefore, the scarcity of studies on the subjects covered in this research increases the importance of this research.

\section{Method}

\subsection{Research Model}

Relational screening model is used in this study. The screening model is a research approach that aims to describe a past or present situation as it is. In the relational screening model, research is conducted to determine the existence and/or degree of co-variance between two or more variables (Karasar, 2004, 2008). Descriptive research is research that aims to determine a situation and to obtain a description and definition of the subject or activities of interest (Şavran, 2009). The current research is a descriptive research since it is aimed to determine the self-talk and mental toughness levels of kick boxers within the scope of the study (it is aimed to reveal the current situation) while it is also an exploratory relational research since it deals with the relationship between both variables (Cresswell, 2005; Fraenkel \& Wallen, 2009). 


\subsection{Research Group}

The study group of the research consists of national and non-national athletes $(n=223)$ who participated in the competitions held before Covid 19, determined by the convenience sampling method (Bishop, 2017), which is one of the non-probability sampling methods. In the literature, it is recommended that the number of participants be 5 to 10 times the number of items in the scale when determining the sample size (Bryman \& Cramer, 2001; Pett, Lackey \& Sullivan, 2003). The fact that there are a total of 25 items/statements in the 2 scales used in the study shows the suitability of 223 athletes for the number of participants. $120(53.8 \%)$ of the athletes are women and 103 $(46.2 \%)$ are men.

\subsection{Data Collection Tools}

In the first part of the current study, various questions regarding the personal information of the participants are included. In the other parts, Self-Talk Questionnaire and Sport Mental Toughness Questionnaire statements are included.

In the study, the "Self-Talk Questionnaire" developed by Zervas, Stavrou and Psychountaki (2007) and adapted to the Turkish athlete population by Engür (2011) is used. Consisting of 11 questions and 2 sub-dimensions (motivational and cognitive), the questionnaire is 5-point Likert type (1=never, 5=always).

At the same time, the "Sport Mental Toughness Questionnaire" developed by Sheard et al. (2009) is used in the study to determine the level of mental toughness in the sports environment. The Turkish adaptation study has been carried out by Altıntaş and Bayar Koruç (2016). In the inventory, 14 statements are included and 6 of these statements are determined as reverse items $(2,4,7,8,9,10)$. The inventory, which includes 3 sub-dimensions (confidence, control, and continuity), is 4-point Likert type (1=completely false, $4=$ completely true).

\subsection{Research Publication Ethics}

For the research, the ethical approval of the research has been obtained with the decision of the Scientific Research and Publication Ethics Committee of Alanya Alaaddin Keykubat University, Department of Social and Human Sciences, dated 08.06.2021.

\subsection{Data Collection}

Questionnaire method is used as data collection method in the research. Demographic Information Form, Self-Talk Questionnaire and Sport Mental Toughness Questionnaire are used in the research. The data collection phase is carried out by sending the determined scales to the participants via online forms and through voluntary participation. The scales take 5-10 minutes to fill.

\subsection{Data Analysis}

The data obtained from the research are analyzed with the help of IBM SPSS 25 program. Before the data analysis, Skewness and Kurtosis (normal distribution of the data) values are checked to determine whether the data are normally distributed or not. In this direction, pearson correlation, t-test and ANOVA analyses are used. Cronbach Alpha analysis is applied to determine the reliability of the measurement tools. $\mathrm{P}<0.05 / \mathrm{p}<0.01$ significance levels are taken into account in the statistical analysis and interpretation of the data.

Based on this, the relationship between self-talk and mental toughness in kickboxers has been tried to be determined, and the differences in self-talk and mental toughness are examined in line with the demographic information of the athletes. Within the framework of these purposes, answers to the following questions are sought:

Is there a significant relationship between the athletes' Self-Talk Questionnaire and Sport Mental Toughness Questionnaire?

Is there a significant difference between self-talk levels of the athletes and the variables of gender, age, duration of involvement in the branch and nationality status?

Is there a significant difference between the mental toughness levels of the athletes and the variables of gender, age, duration of involvement in the branch and nationality status?

\section{Results}

In this section, firstly, the table showing the frequency distribution according to the demographic characteristics of the research group is given. Afterwards, respectively, the table showing the distribution of the scores of the scales, the table showing the relationship between self-talk and the level of mental toughness, and the result tables showing the difference between the averages of the scales (sub-dimensions) and the demographic variables (gender, age, duration of involvement in the branch and nationality status) are included. 
Table 1. Frequency distributions according to the demographic characteristics of the research group

\begin{tabular}{lcccc}
\hline Variable & Category & $\mathrm{N}$ & $\%$ & Total \\
\hline \multirow{2}{*}{ Gender } & Female & 120 & 53.8 & \multirow{2}{*}{ 223 } \\
& Male & 103 & 46.2 & \\
\hline \multirow{4}{*}{ Age } & Age 15-18 & 72 & 32.3 & \\
& Age 19-22 & 88 & 39.5 & \multirow{2}{*}{223} \\
& Age 23-26 & 38 & 17.0 & \\
& Age 27 or over & 25 & 11.2 & \\
\hline \multirow{3}{*}{ Interested in kickboxing } & 5 years or less & 97 & 43.5 & \\
& 6-10 years & 94 & 42.2 & \multirow{2}{*}{223} \\
& 11 years or over & 32 & 14.3 & \\
\hline \multirow{2}{*}{ National status } & Yes & 73 & 32.7 & \multirow{2}{*}{223} \\
\hline
\end{tabular}

It is determined that $53.8 \%$ of the athletes included in the study are female, $39.5 \%$ are in the $19-22$ age group, $43.5 \%$ are interested in kickboxing for 5 years or less, and $67.3 \%$ are not national athletes.

Table 2. Distribution of S-TQ and SMTQ scores

\begin{tabular}{lcccccc}
\hline Scales & Item & Mean & Sd & Skewness & Kurtosis & C.Alpha \\
\hline Motivational function (S-TQ) & 7 & 3.84 & 0.969 & -0.776 & 0.124 & 0.92 \\
Cognitive function (S-TQ) & 4 & 3.78 & 0.918 & -0.594 & -0.101 & 0.80 \\
S-TQ & 11 & 3.82 & 0.903 & -0.639 & -0.055 & 0.93 \\
Confidence (SMTQ) & 6 & 3.22 & 0.563 & -0.466 & -0.107 & 0.75 \\
Continuity (SMTQ) & 4 & 3.23 & 0.638 & -0.573 & -0.464 & 0.63 \\
Control (SMTQ) & 4 & 2.01 & 0.724 & 0.379 & -0.629 & 0.71 \\
SMTQ & 14 & 2.88 & 0.457 & -0.111 & -0.139 & 0.77 \\
\hline
\end{tabular}

Note. S-TQ= Self-Talk Questionnaire; SMTQ=Sport Mental Toughness Questionnaire.

When the scores of the athletes included in the study from the 2 sub-dimensions of Self-Talk Questionnaire are examined, it is seen that the highest average score is in the "motivational function" sub-dimension (3.84). It is seen that the Cronbach Alpha internal consistency coefficient is between 0.80 and 0.92 for the sub-dimensions and 0.93 for the total score. When the average scores of the athletes within the scope of the research from the 3 sub-dimensions of the Sport Mental Toughness Questionnaire are examined, it is seen that the highest average score is in the "continuity" sub-dimension (3.23). It is seen that the Cronbach Alpha internal consistency coefficient is between 0.63 and 0.75 for the sub-dimensions. The Cronbach Alpha internal consistency coefficient for the total average score of Sport Mental Toughness Questionnaire is calculated as 0.77.

When the skewness and kurtosis values are examined, it is observed that the data fulfill the normality assumption. According to Tabachnick and Fidell (2007), skewness and kurtosis values being \pm 1.50 is acceptable for normality. From this point of view, it has been decided to apply parametric statistical techniques for the analysis processes for the determination of relationship and difference. 
Table 3. Pearson correlation analysis results between S-TQ and SMTQ

\begin{tabular}{|c|c|c|c|c|c|c|c|c|}
\hline & & 1 & 2 & 3 & 4 & 5 & 6 & 7 \\
\hline \multirow{2}{*}{ 1. Motivational function (S-TQ) } & $\mathrm{R}$ & 1 & & & & & & \\
\hline & $\mathrm{p}$ & & & & & & & \\
\hline \multirow{2}{*}{ 2. Cognitive function (S-TQ) } & $\mathrm{R}$ & $0.786^{* *}$ & 1 & & & & & \\
\hline & $\mathrm{p}$ & 0.000 & & & & & & \\
\hline \multirow{2}{*}{ 3. S-TQ Total } & $\mathrm{R}$ & $0.974 * *$ & $0.907 * *$ & 1 & & & & \\
\hline & $\mathrm{p}$ & 0.000 & 0.000 & & & & & \\
\hline \multirow{2}{*}{ 4. Confidence (SMTQ) } & $\mathrm{R}$ & $0.190^{* *}$ & $0.197 * *$ & $0.203 * *$ & 1 & & & \\
\hline & $\mathrm{p}$ & 0.004 & 0.003 & 0.002 & & & & \\
\hline \multirow{2}{*}{ 5. Continuity (SMTQ) } & $\mathrm{R}$ & $0.229 * *$ & $0.271 * *$ & $0.256 * *$ & $.360 * *$ & 1 & & \\
\hline & $\mathrm{p}$ & 0.001 & 0.000 & 0.000 & 0.000 & & & \\
\hline \multirow{2}{*}{ 6. Control (SMTQ) } & $\mathrm{R}$ & -0.090 & -0.050 & -0.080 & $.143^{*}$ & $.384 * *$ & 1 & \\
\hline & $\mathrm{p}$ & 0.181 & 0.459 & 0.235 & 0.032 & 0.000 & & \\
\hline \multirow{2}{*}{ 7. SMTQ Total } & $\mathrm{R}$ & $0.151 *$ & $0.190^{* *}$ & $0.173 * *$ & $0.736^{* *}$ & $0.762 * *$ & $0.681^{* *}$ & 1 \\
\hline & $\mathrm{p}$ & 0.024 & 0.005 & 0.010 & 0.000 & 0.000 & 0.000 & \\
\hline
\end{tabular}

$* \mathrm{p}<0.05, * \bar{*}<0.01$.

When Table 3 is examined, it is seen that there is a positive and significant relationship between the total average score of Self-Talk Questionnaire and the total average score of Sport Mental Toughness Questionnaire $(\mathrm{R}=0.173$; $\mathrm{p}<0.01)$. According to this, it can be said that as the level of self-talk increases in kickboxers, the level of mental toughness increases.

When Table 3 is examined in terms of sub-dimensions, it is seen that there is a positive and significant relationship between motivational self-talk and mental toughness confidence sub-dimension $(R=0.190 ; p<0.01)$, mental toughness continuity sub-dimension $(\mathrm{R}=0.229 ; \mathrm{p}<0.01)$, and mental toughness total average score $(\mathrm{R}=0.151 ; \mathrm{p}<0.05)$. According to this, it can be said that as the level of motivational self-talk in kickboxers increases, the levels of mental toughness, continuity and confidence in mental toughness increase. In addition, according to Table 3, it is seen that there is a positive and significant relationship between cognitive self-talk and mental toughness confidence sub-dimension $(\mathrm{R}=0.197 ; \mathrm{p}<0.01)$, mental toughness continuity sub-dimension $(\mathrm{R}=0.271 ; \mathrm{p}<0.01)$, and mental toughness total average score $(\mathrm{R}=0.190 ; \mathrm{p}<0.01)$. According to this, it can be said that as the level of cognitive self-talk in kickboxers increases, the levels of mental toughness, continuity and confidence in mental toughness increase.

Table 4. T-test analysis results according to gender variable

\begin{tabular}{|c|c|c|c|c|c|c|}
\hline \multirow{2}{*}{ Scale } & \multicolumn{2}{|c|}{ Female (120) } & \multicolumn{2}{|c|}{ Male (103) } & \multirow{2}{*}{$\mathrm{t}$} & \multirow{2}{*}{$\mathrm{p}$} \\
\hline & Mean & $\mathrm{Sd}$ & Mean & $\mathrm{Sd}$ & & \\
\hline Motivational function & 4.03 & 0.873 & 3.63 & 1.035 & 3.082 & $0.002 *$ \\
\hline Cognitive function & 3.89 & 0.857 & 3.66 & 0.975 & 1.816 & 0.071 \\
\hline$\underline{\text { Self-talk (Total) }}$ & 3.98 & 0.821 & 3.64 & 0.964 & 2.774 & $0.006^{*}$ \\
\hline Confidence & 3.15 & 0.543 & 3.31 & 0.576 & -2.158 & $0.032 *$ \\
\hline Continuity & 3.28 & 0.617 & 3.18 & 0.662 & 1.162 & 0.247 \\
\hline Control & 2.00 & 0.650 & 2.01 & 0.805 & -0.171 & 0.865 \\
\hline Mental toughness (Total) & 2.86 & 0.445 & 2.90 & 0.472 & -0.743 & 0.459 \\
\hline
\end{tabular}

$* \mathrm{p}<0.05$.

The analyses show that there is a significant difference in the average scores of self-talk $(t=2.774, p<0.05)$ and motivational self-talk sub-dimensions $(t=3.082, \mathrm{p}<0.05)$ according to the gender of the athletes. According to this, it is understood that female athletes' total average self-talk level and "motivational function" sub-dimension average scores are higher than male athletes. In addition, it is seen that there is no significant difference in the cognitive self-talk levels of the athletes $(t=1.816, \mathrm{p}>0.05)$ according to their genders.

In addition, it is seen that there is a significant difference in the mental toughness confidence sub-dimension $(\mathrm{t}=-2.158, \mathrm{p}<0.05)$ according to the genders of the athletes. According to this, it is understood that male athletes' 
confidence levels regarding mental toughness are higher than female athletes. However, it is seen that there is no significant difference according to gender in the mental toughness total average score $(\mathrm{t}=-0.743, \mathrm{p}>0.05)$, mental toughness continuity $(\mathrm{t}=1.162, \mathrm{p}>0.05)$ and control sub-dimension average scores $(\mathrm{t}=-0.171, \mathrm{p}>0.05)$ (Table 4$)$.

Table 5. ANOVA analysis results according to age variable

\begin{tabular}{|c|c|c|c|c|c|c|c|c|c|c|}
\hline \multirow[t]{2}{*}{ Scale } & \multicolumn{2}{|c|}{$\begin{array}{c}15-18 \text { age } \\
(78)\end{array}$} & \multicolumn{2}{|c|}{$\begin{array}{c}19-22 \text { age } \\
(125)\end{array}$} & \multicolumn{2}{|c|}{$\begin{array}{c}23-36 \text { age } \\
(38)\end{array}$} & \multicolumn{2}{|c|}{$\begin{array}{c}27 \geq \text { age } \\
(124)\end{array}$} & \multirow[t]{2}{*}{$\mathrm{F}$} & \multirow[t]{2}{*}{$\mathrm{p}$} \\
\hline & Mean & $\mathrm{S}$ & Mean & $\mathrm{S}$ & Mean & $\mathrm{S}$ & Mean & $\mathrm{S}$ & & \\
\hline Motivational function & 3.78 & 0.971 & 3.79 & 1.007 & 3.95 & 0.9 & 4.06 & 0.939 & 0.777 & 0.508 \\
\hline Cognitive function & 3.61 & 0.953 & 3.84 & 0.904 & 3.89 & 0.848 & 3.92 & 0.951 & 1.35 & 0.259 \\
\hline$\underline{\text { Self-talk (Total) }}$ & 3.72 & 0.915 & 3.81 & 0.911 & 3.93 & 0.858 & 4.01 & 0.913 & 0.862 & 0.462 \\
\hline Confidence & 3.16 & 0.593 & 3.21 & 0.555 & 3.25 & 0.58 & 3.42 & 0.449 & 1.408 & 0.241 \\
\hline Continuity & 3.09 & 0.706 & 3.29 & 0.581 & 3.35 & 0.547 & 3.28 & 0.719 & 1.892 & 0.132 \\
\hline Control & 1.94 & 0.695 & 2.08 & 0.721 & 1.88 & 0.716 & 2.12 & 0.826 & 1.034 & 0.378 \\
\hline Mental toughness (Total) & 2.79 & 0.476 & 2.91 & 0.459 & 2.89 & 0.444 & 3.01 & 0.392 & 1.669 & 0.175 \\
\hline
\end{tabular}

$* \mathrm{p}<0.05$.

ANOVA test results show that there is no significant difference in the total average score of self-talk level $(\mathrm{F}=0.862, \mathrm{p}>0.05)$ and motivational function/cognitive function sub-dimension scores $(\mathrm{F}=0.777$, $\mathrm{p}>0.05 / \mathrm{F}=1.350, \mathrm{p}>0.05)$ according to the age of the athletes. In addition, Table 5 shows that there is no significant difference in the total average score of mental toughness level $(\mathrm{F}=1.669, \mathrm{p}>0.05)$ and confidence/toughness/control sub-dimension scores $(\mathrm{F}=1.408, \mathrm{p}>0.05 / \mathrm{F}=1.892, \mathrm{p}>0.05 / \mathrm{F}=1.034, \mathrm{p}>0.05)$ according to the age of the athletes (Table 5).

Table 6. ANOVA analysis results according to the variable of involvement in kickboxing

\begin{tabular}{|c|c|c|c|c|c|c|c|c|}
\hline \multirow[t]{2}{*}{ Scale } & \multicolumn{2}{|c|}{$\begin{array}{c}5 \leq \text { year } \\
(151)\end{array}$} & \multicolumn{2}{|c|}{$\begin{array}{c}\text { 6-10 year } \\
(86)\end{array}$} & \multicolumn{2}{|c|}{$\begin{array}{c}11 \geq \text { year } \\
(128)\end{array}$} & \multirow[t]{2}{*}{$\mathrm{F}$} & \multirow[t]{2}{*}{$\mathrm{p}$} \\
\hline & Mean & $\mathrm{Sd}$ & Mean & $\mathrm{Sd}$ & Mean & $\mathrm{Sd}$ & & \\
\hline Motivational function & 3.77 & 0.986 & 3.88 & 0.929 & 3.96 & 1.046 & 0.566 & 0.569 \\
\hline Cognitive function & 3.63 & 0.984 & 3.9 & 0.779 & 3.88 & 1.047 & 2.283 & 0.104 \\
\hline Self-talk (Total) & 3.72 & 0.945 & 3.89 & 0.816 & 3.93 & 1.008 & 1.096 & 0.336 \\
\hline Confidence & 3.12 & 0.584 & 3.29 & 0.536 & 3.32 & 0.545 & 2.79 & 0.064 \\
\hline Continuity & 3.13 & 0.629 & 3.26 & 0.65 & 3.45 & 0.588 & 3.098 & $0.047 *$ \\
\hline Control & 2.01 & 0.728 & 1.99 & 0.744 & 2.04 & 0.672 & 0.044 & 0.957 \\
\hline Mental toughness (Total) & 2.81 & 0.472 & 2.91 & 0.436 & 2.99 & 0.453 & 2.469 & 0.087 \\
\hline
\end{tabular}

$* p<0.05$.

ANOVA test results show that there is no significant difference in Self-Talk Questionnaire total average score $(\mathrm{F}=1.096, \mathrm{p}>0.05)$ and motivational function/cognitive function sub-dimension average scores $(\mathrm{F}=.566$, $\mathrm{p}>0.05 / \mathrm{F}=2.283, \mathrm{p}>0.05$ ) according to the duration of involvement in kickboxing. In addition, in Table 6 , it is seen that there is a significant difference in the average scores of the mental toughness level "continuity" sub-dimension $(\mathrm{F}=3.098, \mathrm{p}<0.05)$ according to the duration of involvement of the athletes. According to the results of the Post-Hoc Tukey test, which has been conducted to see among which groups there is a significant difference regarding the differences, it is understood that the continuity levels of mental toughness of the athletes who are interested in kickboxing for " $\geq 11$ years" are higher than those who are interested in kickboxing for $\leq 5$ years and below. However, it is seen that there is no significant difference in the total average score of mental toughness level $(\mathrm{F}=2.469, \mathrm{p}>0.05)$ and average score of confidence/control sub-dimension $(\mathrm{F}=2.790$, $\mathrm{p}>0.05 / \mathrm{F}=.044, \mathrm{p}>0.05$ ) (Table 6). 
Table 7. T-test analysis results according to the nationality status variable

\begin{tabular}{lcccccc}
\hline \multirow{2}{*}{ Scale } & \multicolumn{2}{c}{ National (73) } & \multicolumn{2}{c}{ Non-national (150) } & \multirow{2}{*}{$\mathrm{t}$} & $\mathrm{p}$ \\
& Mean & $\mathrm{Sd}$ & Mean & $\mathrm{Sd}$ & & \\
\hline Motivational function & 4.02 & 0.936 & 3.76 & 0.977 & 1.895 & 0.059 \\
Cognitive function & 4.04 & 0.82 & 3.66 & 0.94 & 2.985 & $0.003^{*}$ \\
Self-talk (Total) & 4.03 & 0.856 & 3.72 & 0.911 & 2.396 & $0.017^{*}$ \\
\hline Confidence & 3.36 & 0.537 & 3.15 & 0.564 & 2.645 & $0.009^{*}$ \\
Continuity & 3.36 & 0.559 & 3.17 & 0.666 & 2.135 & $0.034^{*}$ \\
Control & 2.04 & 0.701 & 1.99 & 0.733 & 0.559 & 0.577 \\
Mental toughness (Total) & 2.99 & 0.414 & 2.82 & 0.469 & 2.504 & $0.013^{*}$ \\
\hline
\end{tabular}

$* \mathrm{p}<0.05$.

The analyses show that there is a significant difference in the average scores of self-talk $(t=2.396, p<0.05)$ and cognitive self-talk sub-dimensions $(t=2.985, \mathrm{p}<0.05)$ according to the nationality status of the athletes. According to this, it is understood that the self-talk levels of national athletes and cognitive self-talk levels in terms of sub-dimensions are higher than non-national athletes. However, it is determined that there is no significant difference in the motivational self-talk levels of the athletes $(t=1.895, p>0.05)$ according to their nationality status.

In addition, it is seen that there is a significant difference in the total average score of Sport Mental Toughness Questionnaire $(\mathrm{t}=2.504, \mathrm{p}<0.05)$ and the average scores of the confidence/continuity sub-dimension $(\mathrm{t}=2.645$, $\mathrm{p}<0.05 / \mathrm{t}=2.135, \mathrm{p}<0.05$ ) according to the national status of the athletes. It is understood that the mental toughness levels of national athletes and the confidence/continuity levels of mental toughness are higher than non-national athletes. However, it is seen that there is no significant difference in the average scores of the control sub-dimension ( $\mathrm{t}=0.559, \mathrm{p}>0.05)$ regarding mental toughness of the athletes according to their national status (Table 7).

\section{Discussion and Conclusion}

This study has been conducted to determine the relationship between the level of self-talk and mental toughness of kickboxers. 223 national and non-national kickboxers who have participated in the competitions held before Covid 19 have participated in the study. 120 (53.8\%) of the athletes are women and 103 (46.2\%) are men.

As a result of the relationship between Self-Talk Questionnaire and Sport Mental Toughness Questionnaire, it is seen that there is a positive and significant relationship between the total average score of self-talk and the total average score of mental toughness in sports. According to this, it can be said that as the level of self-talk increases in kickboxers, the level of mental toughness increases. In addition, it is determined that there is a positive and significant relationship between motivational and cognitive self-talk and mental toughness total average score. According to this, it can be said that as the level of motivational self-talk and cognitive self-talk in kickboxers increases, mental toughness also increases.

When similar studies are examined, as a result of the study conducted by Gülşen, Şahan, Yıldız, and Yılmaz (2019) on the students of the faculty of sports sciences, it is observed that there is a low positive relationship between mental toughness and motivational self-talk, a moderate positive relationship between mental toughness and cognitive self-talk, and a low positive relationship between mental toughness and self-talk total score. Coulter, Mallett, and Gucciardi (2010) have reported in their study on football players that they talk to themselves when they require mental toughness.

In the results of the analysis made according to the gender variable, it is determined that there is a significant difference in the total average score of self-talk and motivational self-talk sub-dimensions. According to this, it is understood that the self-talk levels of female athletes and motivational self-talk levels in terms of sub-dimensions are higher than male athletes. However, it is seen that there is no significant difference in the cognitive self-talk levels of the athletes according to the gender variable. In addition, it is seen that there is a significant difference in the mental toughness confidence sub-dimension according to the gender of the athletes. According to this, it is understood that male athletes' confidence levels regarding mental toughness are higher than female athletes. However, it is determined that there is no significant difference in the mental toughness total score, continuity and control sub-dimensions of mental toughness according to gender.

The study of Akılveren (2017) on athletes doing individual sports supports the current study. According to Ak1lveren's study, a significant difference is found in the motivational self-talk sub-dimension in terms of gender 
variable. According to this, motivational self-talk levels of female athletes are higher than male athletes. In addition, in the analysis of mental toughness levels according to gender, no difference is observed in the sub-dimensions of continuity and control groups. However, a significant difference is observed in the confidence sub-dimension. According to this, it is understood that male athletes have a higher confidence sub-dimension than female athletes. In Peke's (2020) study on orienteering athletes, it is determined that there is no significant difference in terms of gender variable in the mental toughness, confidence, control and continuity sub-dimensions of the athletes in sports.

In the results of the analysis made according to the age variable, it is determined that there is no significant difference in the total average score of the level of self-talk and the average scores of the motivational function/cognitive function sub-dimension. In addition, it is seen that there is no significant difference in the total average score of the mental toughness level and the sub-dimensions of confidence/toughness/control. According to the results of the analysis, it is concluded that the age variable does not affect self-talk and mental toughness in the current study.

In a study by Karharman (2019) on elite mountain running athletes and in a study by Kurtay (2018) on football players playing in development leagues, no significant difference is found between the mental toughness levels and sub-dimensions of the athletes participating in the competition and the age of the athlete. In a study conducted by Engür (2011) on faculty of sports sciences team athletes, it is observed that there is a negative and significant relationship in the analysis of self-talk motivational function/cognitive function sub-dimensions in terms of age variable. The result of the study by Connaughton et al. (2008) does not support the present study. In the study, when the relationship between mental toughness and age variable of athletes is examined, a significant difference is observed.

In the analysis made according to the duration of involvement in kickboxing, it is seen that there is no significant difference in the total average score of the level of self-talk and the average scores of the motivational function/cognitive function sub-dimension. According to this, there is no relationship between the duration of involvement and self-talk. In addition, it is seen that there is no significant difference in the total average score of the mental toughness level and the average scores of the sub-dimensions of confidence/control. However, it is observed that there is a significant difference in the mental toughness continuity sub-dimension according to the duration of involvement.

In a study conducted by Bayköse (2014) on individual and team athletes, no significant difference is observed in terms of the variable of duration of involvement in the sub-dimensions of self-talk. In Ak1lveren's (2017) study on individual athletes, no significant difference is found between the duration of involvement variable and the mental toughness sub-dimensions of confidence and control. However, a significant difference is found in the continuity sub-dimension of mental toughness level. It is observed that this difference is in favor of the athletes with a high level of involvement. When the literature is examined, there is no significant difference in the studies of Hardy et al. (2005) and Gammage et al. (2001) in terms of the sub-dimensions of self-talk and the duration of involvement variable. The studies carried out show parallelism with the present study.

In the analysis made according to nationality status, it is observed that there is a significant difference in the total average score of self-talk and cognitive self-talk sub-scores. According to this, it is understood that the self-talk levels of national athletes and cognitive self-talk levels are higher than non-national athletes. However, it is seen that there is no significant difference in the motivational self-talk levels of the athletes according to the nationality variable. In addition, it is seen that there is a significant difference in mental toughness total average score and confidence/continuity sub-dimension average scores according to the nationality variable of the athletes. According to this, it is understood that the mental toughness levels of national athletes and the confidence/continuity levels are higher than non-national athletes. However, it is seen that there is no significant difference according to the control sub-dimension of mental toughness and the nationality variable. As a result of the research they carried out with the coaches from Australia who have experience in coaching and sportsmanship at the elite level, Gucciardi et al. (2008) explained mental toughness as the sum of values, attitudes, behaviors and emotions that enable to overcome any pressure, obstacle or difficulty without giving up, as well as maintain concentration and motivation on the way to achieving goals. The positive results of the study in the dimension of national sportsmanship support this explanation. Mental toughness becomes more effective when the given sports training brings the athlete to the point of being national in the performance dimension.

Orhan's (2018) study on individual and team athletes supports the current study. According to the results of Orhan's analysis, no significant difference is observed between the mental toughness control sub-dimension of the nationality variable. However, it is determined that there is a significant difference between the 
confidence/continuity scores of mental toughness sub-dimensions and the nationality variable. According to this, national athletes are more advantageous than non-national athletes in terms of mental toughness level, confidence/continuity sub-dimension. Contrary to the current study, Şahin's (2017) study on Greco-Roman and freestyle wrestlers shows that the athletes do not statistically differ in their motivational function/cognitive function scores, one of the sub-dimensions of self-talk, according to the nationality variable.

In conclusion, the fact that there is a positive and significant relationship between self-talk and mental toughness suggests that self-talk is also a predictor of performance. Because, as mentioned in the introduction, research shows that there is a link between mental toughness and performance. In other words, if the mental toughness increases as the level of self-talk increases in kickboxers, there will also be an increase in sportive performance. The significant positive relationship between the sub-dimensions reveals the importance of motivational and cognitive self-talk in kickboxing. In sports that require individual struggle, the person is faced with their opponent and therefore their own performance. At the point of achieving success, the inner messages that they will give themselves will increase their mental toughness and will be reflected in the sports environment, training or competition.

According to another important result of the study, the self-talk and mental toughness levels seen in national athletes, who are the highest level of sportsmanship, also reveal the strong psychological aspect of the training given through sports training. Based on this, it is thought that the experience formed as a result of training and competitions makes the athlete strong in a spiritual sense.

\section{Recommendations}

- According to the results of the research, a positive relationship is found between the level of self-talk and the level of mental toughness in athletes. In order to improve these levels, online or face-to-face psychological support can be given to the athletes.

- The relationship between self-talk and mental toughness, discussed in the study, can also be examined on other individual sports branches, and thus the psychological effects of sports training in branches can be evaluated by comparing different branches.

- The concepts of self-talk and mental toughness can be studied not only on athletes, but also on trainers, coaches, referees or fans.

- Coaches should determine the methods of self-talk and mental toughness suitable for the training and competitions of the athletes they train and ensure their implementation.

- The relationship between self-talk and mental toughness can be examined as well as its relationship with motivation, anxiety, stress and self-efficacy.

- In the current study, the data have been obtained by online forms due to the pandemic. In future studies, richer information can be collected and stronger data can be obtained by using other sources such as face-to-face or observation.

\section{References}

Açıkada, C., \& Ergen, E. (1990). Bilim ve spor. Ankara: Büro Tek Ofset Matbaacılık.

Akılveren, P. (2017). Sporcuların motivasyonel kendinle konuşma ve zihinsel dayanıklllk düzeyinin incelenmesi. Yüksek Lisans Tezi, Akdeniz Üniversitesi, Sosyal Bilimler Enstitüsü, Spor Yöneticiliği Anabilim Dal, Antalya.

Altıntaş, A., \& Bayar, K. P. (2017). Sporda Zihinsel Dayanıklılık Envanterinin Psikometrik Özelliklerinin İncelenmesi (SZDE). Hacettepe Journal of Sport Sciences, 27(4), 163-171. https://doi.org/10.17644/sbd.311985

Aşc1, F. H., \& Kirazcı, S. (2003). Spor bilimlerinin psikolojik temelleri. In N. Mirzaoğlu (Ed.), Spor Bilimlerine Giriş (pp. 153-196). Ankara: Bağırgan Yayımevi.

Bayköse, N. (2014). Sporcularda kendinle konuşma ve imgeleme düzeyinin optimal performans duygu durumunu belirlemedeki rolü. Yüksek Lisans Tezi, Selçuk Ünversitesi, Sağlık Bilimleri Enstitüsü, Beden Eğitimi ve Spor Anabilim Dalı, Konya.

Bingöl, E. (2020). Dövüş sporcularında motivasyon, kendinle konuşma ve performans arasındaki iliş̧kinin incelenmesi. Doktora Tezi, Sttkı Koçman Üniversitesi, Lisanüstü Eğitim Enstitüsü, Antrenörlük Eğitimi Anabilim Dalı, Muğla.

Bishop, P. A. (2017). Measurement and evaluation in physical activity applications. Exercise Science, Physical 
Education, Coaching, Athletic Training \& Health: Routledge. https://doi.org/10.4324/9781351199711

Bryman, A., \& Cramer, D. (2001). Quantitative data analysis with SPSS release 10 for Windows. London: Routledge Press. https://doi.org/10.4324/9780203471548

Clough, P., Earle, K., \& Sewell, D. (2002). Mental toughness: The concept and tts measurement (1st ed.). In Cockerill I, Solutions in Sport Psychology (pp. 32-45).

Connaughton, D., Wadey, R., Hanton, S., \& Jones, G. (2008). The development and maintenance of mental toughness: perceptions of elite performers. Journal of Sport Sciences, 26(1), 83-95. https://doi.org/10.1080/02640410701310958

Coulter, T. J., Mallett, C. J., \& Gucciardi, D. F. (2010). Understanding mental toughness in Australian soccer: Perceptions of players, parents, and coaches. Journal of Sports Sciences, 28(7), 699-716. https://doi.org/10.1080/02640411003734085

Creswell, J. W. (2005). Educational research: Planning, conducting, and evaluating quantitative and qualitative research (2. Bask1). USA: Pearson Education Inc.

Engür, M. (2011). Performans başarlsızlı̆̆ değerlendirme envanteri ve kendinle konuşma anketinin türk sporcu popülasyonuna uyarlanması ve uygulanması. Doktora Tezi, Ege Üniversitesi, Sağlık Bilimleri Enstitüsü, Sporda Psikososyal Alanlar Anabilim Dalı, İzmir.

Fraenkel, J. R., \& Wallen, N. E. (2009). How to design and evaluate research in education. New York: McGraw-Hill.

Gammage, K. L., Hardy, J., \& Hall, C. R. (2001). A description of self-talk in exercise. Psychology of Sport and Exercise, 2(4), 233-247. https://doi.org/10.1016/S1469-0292(01)00011-5

Gülşen, D. B. A., Şahan, H., Yıldız, A. B., \& Yılmaz, B. (2019). Spor bilimleri fakültesindeki öğrencilerin kendinle konuşma ve zihinsel dayanıklılık düzeyleri arasındaki ilişkinin incelenmesi. Gaziantep Üniversitesi Spor Bilimleri Dergisi, 4(4), 459-470. https://doi.org/10.31680/gaunjss.621767

Hardy, J., Hall. C. R., \& Hardy, L. (2005). Qantifying athlete self-talk. Journal of Sports Sciences, 23(9), 905-917. https://doi.org/10.1080/02640410500130706

Hardy, J., Oliver, E., \& Tod, D. (2009). A framework for the study and application of self-talk within sport. In S. İçinde, D. Mellalieu, \& S. Hanton (Eds.), Advances In Applied Sport Psychology: A Review (pp. 37-74). London: Routledge.

Jackson, S., Thomas, P., Marsh, H., \& Smethurst, C. (2001). Relationships between flow, self-conceptpsychological skills, and performance. Journal of Applied Sport Psychology, 13, 129-153. https://doi.org/10.1080/104132001753149865

Jones, G., Hanton, S., \& Connaughton, D. A. (2007). Framework of mental toughness in the world's best performers. Sport Psychol, 21(2), 243-264. https://doi.org/10.1123/tsp.21.2.243

Karasar, N. (2008). Bilimsel araştırma yöntemi. Ankara: Nobel Yayın Dağıtım.

Karharman, A. (2019). Elit dağ koşusu sporcularında pozitif algl ve zihinsel dayanıklllık düzeylerinin başarı motivasyonu üzerine etkisinin incelenmesi. Doktora Tezi, Muğla Sıtkı Koçman Üniversitesi, Sağlık Bilimleri Enstitüsü, Beden Eğitimi ve Spor Anabilim Dalı, Muğla.

Kurtay, M. (2018). Gelişim liglerinde oynayan futbolcuların zihinsel dayanıklllk düzeylerinin incelenmesi. Yüksek Lisans Tezi, Akdeniz Üniversitesi, Sağlık Bilimleri Enstitüsü, Hareket ve Antrenman Anabilim Dalı, Antalya.

Mahoney, J., Ntoumanis, N., Mallett, C., \& Gucciardi, D. (2014). The motivational antecedents of the development of mental toughness: A self-determination theory perspective. International Review of Sport and Exercise Psychology, 7(1), 184-197. https://doi.org/10.1080/1750984X.2014.925951

Orhan, S. (2018). Bireysel sporcular ve takım sporcularında duygusal zekâ ve zihinsel dayanıklılık ilişsisi. Yüksek Lisan Tezi, Marmara Üniversitesi, Sağlık Bilimleri Enstitüsü, Beden Eğitimi ve Spor Anabilim Dalı, İstanbul.

Peke, K. (2020). Oryantiring katılımcılarının spora bağlllıkları ve zihinsel dayanıklılıklarının incelenmesi. Yüksek Lisans Tezi, İstanbul Gelişim Üniversitesi, Lisanüstü Eğitim Enstitüsü, Antrenörlük Eğitimi Anabilim Dalı, İstanbul.

Pett, M. A., Lackey, N. R., \& Sullivan, J. J. (2003). Making sense of factor analysis: The use of factor analysis 
for instrument development in health care research. CA: Sage. https://doi.org/10.4135/9781412984898

Şahin, A. (2017). Grekoromen ve serbest stil güreş yapan sporcuların kendileriyle konuşma düzeylerinin incelenmesi. Kilis 7 Aralık Üniversitesi Beden Eğitimi ve Spor Bilimleri Dergisi, 1(1), 60-64.

Şavran, G. T. (Ed). (2009). Sosyolojide araştırma yöntem ve teknikleri. Eskişehir: Anadolu Üniversitesi Yayını.

Shannon, V. R., Gentner, N. B., Patel, A., \& Muccio, D. (2012). Striking gold: mental techniques and preparation strategies used by olympic gold medalists. Athletic Insight, 4(1), 1.

Sheard, M., Golby, J., \& Van Wersch, A. (2009). Progress towards construct validation of the Sports Mental Toughness Questionnaire (SMTQ). European Journal of Psychological Assessment, 25, 186-193. https://doi.org/10.1027/1015-5759.25.3.186

Tabachnick, B. G., \& Fidell, L. S. (2013). Using multivariate statistics (6th ed.). Boston.

Thelwell, R. C., Weston, N. J., Greenlees, I. A., \& Hutchings, N. V. (2008). A qualitative exploration of psychological-skills use in coaches. The Sport Psychologist, 22, 3853. https://doi.org/10.1123/tsp.22.1.38

Vargas-Tonsing, T. M., Myers, N. D., \& Feltz, D. L. (2004). Coaches' and athletes' perceptions of efficacy-enhancing techniques. Sport Psychologist, 18(4), 397-414. https://doi.org/10.1123/tsp.18.4.397

Weinberg, R. S., \& Gould, D. (2014). Human kinetics. Foundations of Sport and Exercise Psychology, 6E.

Zervas, Y., Stavrou, N., \& Psychountaki M. (2007). Development and Validation of the Self-Talk Questionnaire

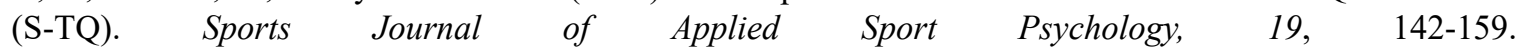
https://doi.org/10.1080/10413200601185156

\section{Copyrights}

Copyright for this article is retained by the author(s), with first publication rights granted to the journal.

This is an open-access article distributed under the terms and conditions of the Creative Commons Attribution license (http://creativecommons.org/licenses/by/4.0/). 